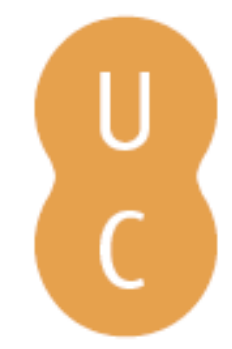

pnmbalina

\title{
Nutrient dynamics in the intertidal pools of the Mondego estuary: I - nutrient sources, sediment profiles, mineralisation and absorption dynamics
}
Autor(es):
Flindt, Mogens René; Pardal, Miguel Ângelo; Lillebo, Ana Isabel;
Oliveira, José Miguel

Publicado por: Imprensa da Universidade de Coimbra

URL persistente:

URI:http://hdl.handle.net/10316.2/32679

DOI:

DOl:http://dx.doi.org/10.14195/978-989-26-0336-0_15

Accessed : $\quad$ 26-Apr-2023 12:35:11

A navegação consulta e descarregamento dos títulos inseridos nas Bibliotecas Digitais UC Digitalis, UC Pombalina e UC Impactum, pressupõem a aceitação plena e sem reservas dos Termos e Condições de Uso destas Bibliotecas Digitais, disponíveis em https://digitalis.uc.pt/pt-pt/termos.

Conforme exposto nos referidos Termos e Condições de Uso, o descarregamento de títulos de acesso restrito requer uma licença válida de autorização devendo o utilizador aceder ao(s) documento(s) a partir de um endereço de IP da instituição detentora da supramencionada licença.

Ao utilizador é apenas permitido o descarregamento para uso pessoal, pelo que o emprego do(s) título(s) descarregado(s) para outro fim, designadamente comercial, carece de autorização do respetivo autor ou editor da obra.

Na medida em que todas as obras da UC Digitalis se encontram protegidas pelo Código do Direito de Autor e Direitos Conexos e demais legislação aplicável, toda a cópia, parcial ou total, deste documento, nos casos em que é legalmente admitida, deverá conter ou fazer-se acompanhar por este aviso.

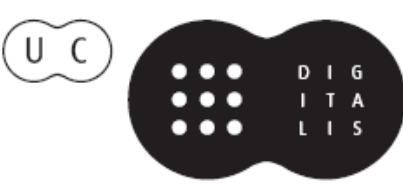


MIGUEL ÂNGELO PARDAL JOÄO CARLOS MARQUES MANUEL AUGUSTO GRAÇA Scientific Editors

\section{Aquatic Ecology of the Mondego River Basin Global Importance of Local Experience}




\author{
MIGUEL ÂNGELO PARDAL \\ JOẢO CARLOS MARQUES \\ MANUEL AUGUSTO GRAÇA \\ Scientific Editors
}

\title{
Aquatic Ecology of the Mondego River Basin Global Importance of Local Experience
}




COORDENAÇÃO EDITORIAL
Imprensa da Universidade de Coimbra
CONCEPÇÃO GRAFICA
António Barros
INFOGRAFIA
António Resende
Estimulus [design] • Coimbra
EXECUÇÃO GRAFICA
GRAFIASA
ILUSTRAÇÃO DA CAPA
P. P. Cunha e ]. Dinis
ISBN
972-8704-04-6
DEPOSITO LEGAL
I75038/02

(C) JANEIRO 2002, IMPRENSA DA UnIVERSIDADE DE COIMBRA

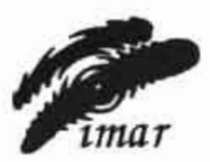

CPIMAR

imar

OBRA PUBLICADA COM O PATROCINIO DE:

IMAR - INSTITUTO DO MAR

IPIMAR - INSTITUTO DE INVESTIGAÇĀO DAS PESCAS E DO MAR 

MOGENS RENE FLINDT ${ }^{1}$

Miguel ÂNGelo PARDAL 2

ANA ISABEL LILLEBO ${ }^{2}$

IRENE MARTINS ${ }^{2}$

José Miguel OLiveira ${ }^{2}$

\title{
NUTRIENT DYNAMICS INTHE INTERTIDAL POOLS OFTHE MONDEGO ESTUARY. \\ I - NUTRIENTS SOURCES, SEDIMENT PROFILES, MINERALISATION AND ADSORPTION DYNAMICS
}

\begin{abstract}
During ebb situations in tidal estuaries with high tidal amplitude most of the system is out of water. In this period intertidal pool formation takes place in very extended areas. These pools differ with respect to internal nutrient loading, hydraulic conditions, duration. plant coverage, sediment properties such as organic content in the sediment, C/N/P-ratios of the sediment nutrient sources and porewater concentrations of nutrients.

Therefore, the objective was to study and compare the nutrient sources and dynamics in different types of intertidal pools of the Mondego estuary. In each intertidal pool the nutrient dynamics were followed on a seasonal scale by measuring oxygen dynamic, phosphate, ammonia, nitrate besides physical parameters as salinity, temperature, sediment organic matter, sediment total phosphorus, potential phosphate adsorption, total sediment nitrogen, sediment water content, pool volume and pool area.

The results showed that the nutrient dynamics in shallow intertidal pools are much faster than in subtidal areas. This is most probably due to the shallowness of the systems giving anabolic as well as catabolic processes optimal conditions with respect to light climate, oxygen concentrations, higher concentrations of dissolved inorganic nutrient and higher mean temperature during the growth season. Altogether, this study indicate that in the Spartina maritima covered areas the plants are able to control the phosphorus dynamic due to Spartina maritima take up phosphate for growth purposes, that without plant coverage would have returned to the watercolumn and that Spartina do also facilitates the increased phosphate adsorption. On the system level most pools are situated on bare bottom without connection to rooted vegetation, and these leaks with substantial amounts of phosphate. So the intertidal pool system of the Mondego estuary altogether are exporting significant amounts of phosphorus in these years.
\end{abstract}

\footnotetext{
in Biological Institute, SDU - University of Odense, Campusvej 55.5230 Odense M. Denmark

(2) IMAR - Instituto do Mar. Centro Interdisciplinar de Coimbra a/c Departamento de Zoologia. Universidade de Coimbra. 3004-517 Coimbra. Portugal
} 


\section{Introduction}

Estuaries represent gradient in both physical, chemical and biological processes and their function as filters for dissolved and particulate nutrients from land drainage is determined by these gradients (Shubel and Kennedy 1984, Nixon 1995). The longitudinal gradients of nutrients created by dilution, dispersion and loss processes over short stretches make estuaries ideal for studies of nutrient dynamics (Borum 1997). From a physical point of view the deposition of fluvial material depends on the gravitational circulation pattern, sediment stability and the basin bathymetry, but also processes like flocculation are important (Pejrup et al. 1997, Amos et al. 1998). The physical-geochemical deposition is leaving dissolved nutrients for biological uptake in the watercolumn followed by sedimentation. Or alternatively by nutrient uptake for anabolic purposes at the sediment surface. The study of the close benthic-pelagic coupling of nutrient dynamics and the net losses of nutrients in estuaries therefore requires description of both transport-dispersion and biogeochemical processes. And only proper mass balances can verify whether an area inside the estuary acts as a source or a sink for nutrients.

Earlier, mass balances for the Mondego estuary were calculated (Flindt et al. 1997. Pardal 1998), where about 14 tons of phosphorus where missing. The question was where to search for this deficit? Was it caused by incorrect land based discharge or mixing at the outer boundary? Not with an order of magnitude! Being out in the field area, we recognised that although most of the area is submerged during high tide, when the water level drops during the ebb most of the system is out of the waterphase. In this situation tidal pools formation takes place in very extended areas. The pool size can vary from $\mathrm{cm}^{2}$ only holding ml's of water up to several $\mathrm{m}^{2}$ with volumes reaching $\mathrm{m}^{3}$. Almost nothing is presented in the literature about the nutrient dynamics in small intertidal pools. Moreover, depending on the topographic conditions, these shallow tidal pools will remain either for a short period or during the whole ebb phase. The long existing pools have a duration of about eight to ten hours, before the next flood reach them and the water become mixed with the estuarine channel water. During this long period the water temperature increases dramatically facilitating high mineralization rates of organic matter, organic nitrogen and phosphorus (Lillebø et al. $2002 b$ ). Furthermore, during night ebbs these pools may become anoxic, when microphytobentos, macroalgae and rooted macrophytes are unable to compensate the heterotrophic oxygen consumption. Under such conditions, the adsorbed phosphate releases from the adsorption sites and diffuses to the porewater resulting in increased phosphate efflux from the sediment to the water column.

Altogether, the enhanced nutrient dynamics in the pools, the differences in the sediment properties, and the topography may support macroalgae growth rates that differs from the rates recognised during high tide. Only the fact that the macroalgae never become light limited in the shallow pools changes the growth potential completely. These changes together with the fast nutrient tumover in the intertidal pools may be of significant importance for the nutrient dynamics of the whole estuary and influence the seasonal export balance of nutrients from the system. 
In this suite of four papers we share a major objective by studying if different intertidal pools function as a source or a sink for nutrients in the Mondego estuary. The work is separated into the following topics:

I. Nutrient pools, nutrient sediment profiles, nutrient mineralisation and phosphorus adsorption dynamics.

II. Seasonal efflux of $\mathrm{PO}_{4}-\mathrm{P}$ and $\mathrm{NH}_{4}-\mathrm{N}$ in bare bottom and vegetated pools.

III. The importance of nutrient effluxes to macroalgal growth (Enteromorpho sp.).

IV. Pools contribution to the dissolved inorganic phosphate loading.

The selected pool types were considered as representative for the salt marsh area of the estuary. Inside this area all kinds of dominating sediment types was represented. The chosen pools were Spartina maritima covered muddy pools, sandy and muddy bare bottom pools with different amount of organic matter, and nitrogen and phosphorus content. By repeating the studies during day and night periods and over the season net efflux calculations could be made and the export/import balance for the nutrients from the different pool areas will appear.

\section{Study site}

General information and more detailed description of the Mondego estuary can be found in Marques et al. (2002). Figure I shows the placement of the different sites and the pool that was used in the present study. The sandy pools had the shortest duration of about 3 hours, while the Spartina and the muddy pools lasted for 8-10 hours depending on the tidal phase. So the intertidal pools differed with respect to hydraulic conditions, residence time, plant coverage and organic content in the sediment, porewater profiles of phosphate, ammonia and nitrate.

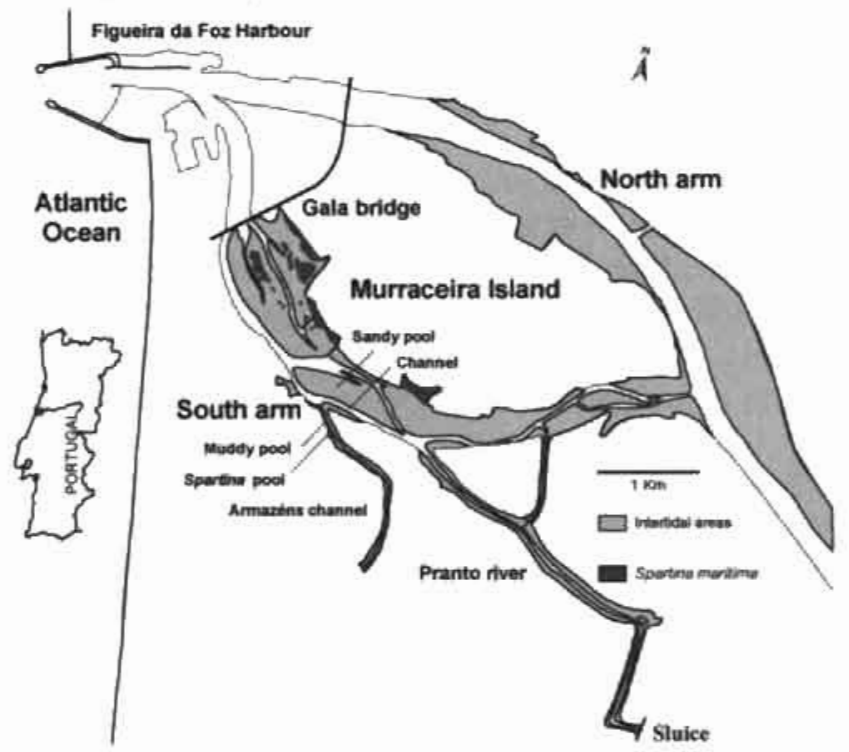

Fig. 1. Map of the Mondego Estuary including the location of our intertidal pools. 


\section{Material and Methods}

From the formation of each pool when the high tide faded the nutrient dynamics were followed in the watercolumn of each type pool. This was realised by measuring concentrations of oxygen, phosphate and ammonia with a temporal resolution of I hour. In addition physical parameters as salinity, temperature, pool volume and pool area was measured.

Three sediment cores were harvested from each pool in July 1997 and brought to the laboratory where they were sectioned into $1 \mathrm{~cm}$ subcores. All subcores from the same depth interval were initially mixed to improve the homogenity among the samples. Triplicate subsamples were analysed for sediment water content, dry matter ( $105^{\circ} \mathrm{C}$ in 24 hours), loss of ignition ( $550^{\circ} \mathrm{C}$ in 6 hours), total phosphorus, potential phosphate adsorption capacity and total nitrogen.

Phosphate adsorption measurements were done as a saturation kinetic experiment on the same subcores used for measurements of the other sediment parameters. All analysis were performed by methods appropriate for the ambient salinity according to Standard methods (1996). The adsorption of phosphate was measured over a broad range of phosphate concentrations. Eight subsamples from each sediment layer (about $1.0 \mathrm{~g}$ wwt sediment) were exposed to increasing concentrations of phosphate ranging from: $0.0-5 \mathrm{mg} \mathrm{PO}+\mathrm{P} \mathrm{I}^{-}$. The experiments were done in $250 \mathrm{ml}$ open medical glass bottles where the sediment was suspended with $200 \mathrm{ml}$ pre-filtered estuarine water. Afterward, the bottles were placed in a shaking bath for 36 hours and the adsorption or desorption of phosphate were measured following the method used by Jensen et al. (1992) The measured adsorption ( $\mu \mathrm{g}$ PO. $P g^{\prime}$ dwt sediment) was afterward statistical fitted to the non-linear saturation Langmuir expression:

$$
\mathrm{SP}=\left(\mathrm{PSC}{ }^{*} \mathrm{Ce}\right) /(\mathrm{Ce}+\mathrm{K})-\mathrm{NAP}
$$

where SP is the adsorption of phosphate in $\mathrm{mg} \mathrm{g}^{\prime}$ dwt sediment, $\mathrm{Ce}$ is the final phosphate concentration, $K$ is the half saturation constant, PSC is the Phosphate Sorption Capacity (maximal adsorption capacity) and NAP is the Native Adsorbed Phosphate (the adsorption at concentration $0.0 \mu \mathrm{g} \mathrm{PO}_{4}-\mathrm{P}^{-1}$ ). The SAS non-linear regression model was used to find PSC, $K$ and NAP.

Experiments of the quality of the organic matter in the sediment were performed

246 for each inter tidal pool. The sediment cores were harvested in July 1997. These experiments were performed as mineralization studies, where $2 \times 10 \mathrm{~g}$ wnt of sediment from the depth range of $0.0-5.0 \mathrm{~cm}$ represented each pool. At time zero. the particulate organic nitrogen (PON) were measured in all samples representing the initial $100 \%$ of PON in each intertidal pool. The well-mixed sediment was transferred into $250 \mathrm{ml}$ glass bottles, and afterwards added $200 \mathrm{ml}$ pre-filtered estuarine water. All bottles were incubated in darkness at $18^{\circ} \mathrm{C} \pm 1{ }^{\circ} \mathrm{C}$. At each time interval a subsample of the sediment were taken and measured at a Carlo Alba CHN-analyser. It was decided that the experiments terminated when the mineralization of the sediment 
particulate organic matter had entered a slowly and stable mineralization pattern without further nutrient dynamics. Subsamples were taken at day 0, 5, 10, 20, 30, 40 , 50.60 and 70 when this mineralization experiment was finished.

All dissolved inorganic nutrient analyses were measured on a rapid flow autoanalyzer (RFA 300 Alpkem) and performed by methods appropriate for the ambient salinity according to Alpkem methodologies (Alpkem 1990).

\section{Results}

Sediment properties

The sediment water content was measured in the upper $15 \mathrm{~cm}$ in all the different pools. The water content in the Spartina pools was about $75 \%$ at the sediment watercolumn interface, which decreases to about $55 \%$ in the lower part of the core. In the bare muddy sediment the water content was $95 \%$ in the top decreasing to $80 \%$ in $12.5 \mathrm{~cm}$ depth. The sandy pools had the driest sediment with a water content of 50 $\%$ in the interface decreasing to about $25 \%$ in the deepest part.
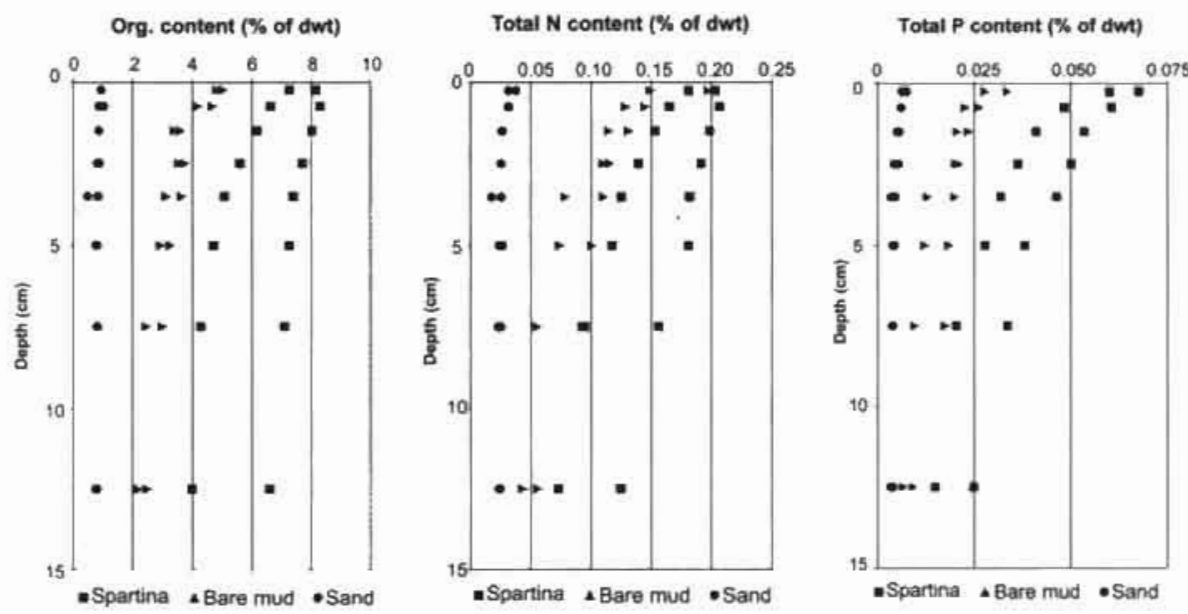

Fig. 2. Sediment organic matter content (a), nitrogen (b) and phosphorus content (c) measured as $\%$ of the sediment dry weight.

The organic content of the different pools is shown in Figure 2a. It was about $8 \%$ in the upper part of the Spartina sediment decreasing continuously to about $4-6 \%$ in $12.5 \mathrm{~cm}$ depth. The muddy bare bottom sediments had an organic content of about $5 \%$ in the top decreasing to about $2 \%$ in the bottom, while the sandy bare bottom sediments had the lowest organic content with $0.95 \%$ in the surface without any depth variations. The total nitrogen content was again the highest in the Spartina covered pools where the values were about $0.2 \%$ total nitrogen in the top part decreasing to 
about $0.1 \%$ in the deepest layer (Fig. 2b). The muddy bare bottom sediment had about $0.15-0.2 \%$ in the sediment surface, which continuously decreased to $0.5 \%$ in $7.5 \mathrm{~cm}$ depth without any further variation downward. The total nitrogen content in the sandy bare bottom pools was about $0.04 \%$ without any consistent changes with depth (Fig. 2.b). The total phosphorus content was also highest in the Spartino pools with about $0.06 \%$ in the sediment surface reaching 0.02 in $12.5 \mathrm{~cm}$ depth with a well-defined gradient (Fig. 2.c). The muddy bare bottom content of total phosphorus was only 0.03 $\%$ in the surface decreasing to about $0.01 \%$ in the bottom. The sandy bare bottom sediment was again the lowest with only $0.01 \%$ of total phosphorus in the surface decreasing to about $0.005 \%$ in the bottom (Fig.2.C).

Nitrogen mineralisation experiments.

It is assumed that this type of mineralisation experiments carried out in the laboratory verify how much of the nitrogen pools that becomes mineralised (Nixon 1981. Klump and Martens 1983) and thereby is exchangeable between the sediment and the watercolumn (Kamp-Nielsen 1992). The non-mineralised fraction after these 70 days are assumed to be less labile to microbial degradable and therefor has a very long turnover time. The results are shown in Figure 3. The mineralization experiment shows the general tendency with highest initial mineralization rates that decreases over time. Major differences existed between the amount of mineralised nitrogen in the different pools. Within the first 10 days of the experiment $20 \%$ of the PON were mineralised in the Spartina pool while only $10 \%$ were mineralised in the muddy pools and $5 \%$ in the sandy pools. In the end of the experiment about $50 \%$ of the sediment PON from the Spartina pools was mineralised while about $30 \%$ of the PON from the muddy pools and only $20 \%$ of the PON from the sandy pools was mineralised.

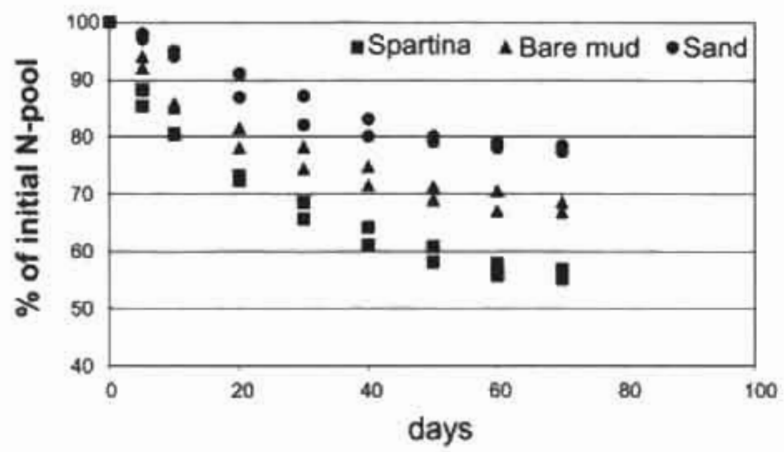

Fig. 3. Sediment particulate nitrogen (PON) mineralisation at the three study sites. The inrial amount of PON was set to $100 \%$.

Based on the above experimental data, mineralisation rate constants were calculated for the PON in the respective pool types. The results are shown in Fig. 4. The rate constants obtained in the Sportina pool indicate that three nitrogen sources with different lability became mineralised. The first fast source was mineralised within 
the first 10 days with a rate constant of about $0.02 d^{\prime}$, while the lesser labile source with an average rate constant of about 0.01 d' was only used at day 40 . The less labile nitrogen source with a rate constant of $0.005 d^{\prime}$ continued throughout the experimental period until day 70 . The initial mineralization rate constant in the bare muddy pools was about the half of the Spartina value, and became used until day 20 , while the rate constant for the last nitrogen sources only was a little lesser than the final Spartina source. It seems likely that there is only one particulate nitrogen source In the sandy pools, due to the fact that there were no changes in the mineralisation rate constant throughout the experiment. The rate stayed low throughout the experiment ranging between $0.004-0.006 \mathrm{~d}$.

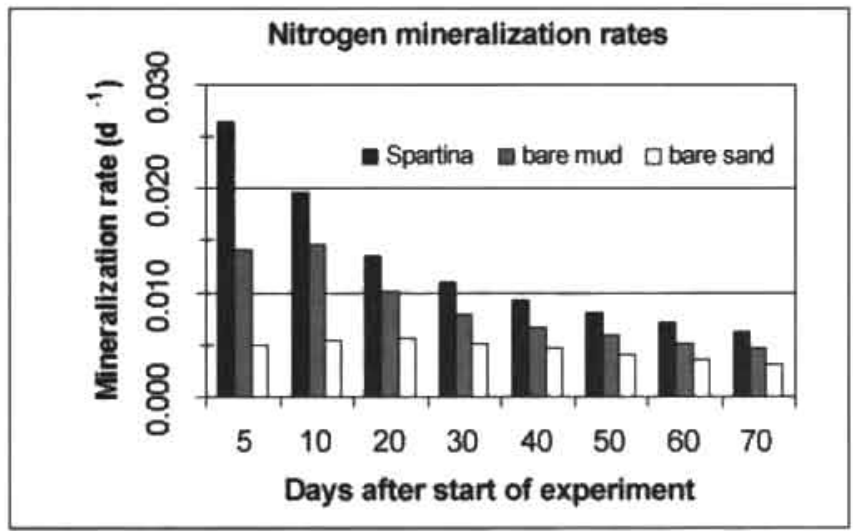

Fig. 4. Dynamics in the sediment mineralisation rate constant during experiments.

Porewater profiles of dissolved inorganic nutrients.

There were very pronounced differences in porewater concentrations of dissolved inorganic nutrients between the locations and from summer to fall/winter.

Phosphate porewater profiles.

Comparing bare sandy and muddy pools in the summer, the porewater concentrations of phosphate was $0.02-0.04 \mathrm{mg} \mathrm{PO}+-\mathrm{PH}^{-1}$ in the sandy sediment water interface while the concentration in the muddy pools reached about $0.2 \mathrm{mg} P \mathrm{O}_{+}-\mathrm{P} \mathrm{I}$ ! At the sandy pool the concentration never increased above $0.6 \mathrm{mg} \mathrm{PO}_{4} \mathrm{P}^{-1}$ in the depth, while it reached a concentration of more than $4 \mathrm{mg} \mathrm{PO} \mathrm{A}_{4}-\mathrm{P} \mathrm{I}^{\prime}$ in the deepest part of the muddy porewater (Fig. 5.a). In the Sportina covered muddy sediments phosphate was very depressed in the upper part of the thizosphere $(0-8 \mathrm{~cm}$ depth) with a concentration range of $0.2-0.4 \mathrm{mg} \mathrm{PO}-\mathrm{P} \mathrm{I}^{-1}$ compared to the bare muddy pools where the concentration was $1.5-2.8 \mathrm{mg} \mathrm{PO}_{-} \mathrm{Pl}^{\prime}$ at the same depth. Deeper in the sediment $(8-15 \mathrm{~cm}$ depth) the concentrations equalised. The fall/winter profiles of the sandy area was slightly higher (Fig 5.d). In the deeper parts of the sediment. the concentration was about $1 \mathrm{mg} \mathrm{PO}_{4}-\mathrm{P} \mathrm{r}^{\mathrm{t}}$. In the muddy area the $\mathrm{PO}_{4}-\mathrm{P} \mathrm{H}^{+}$profile 

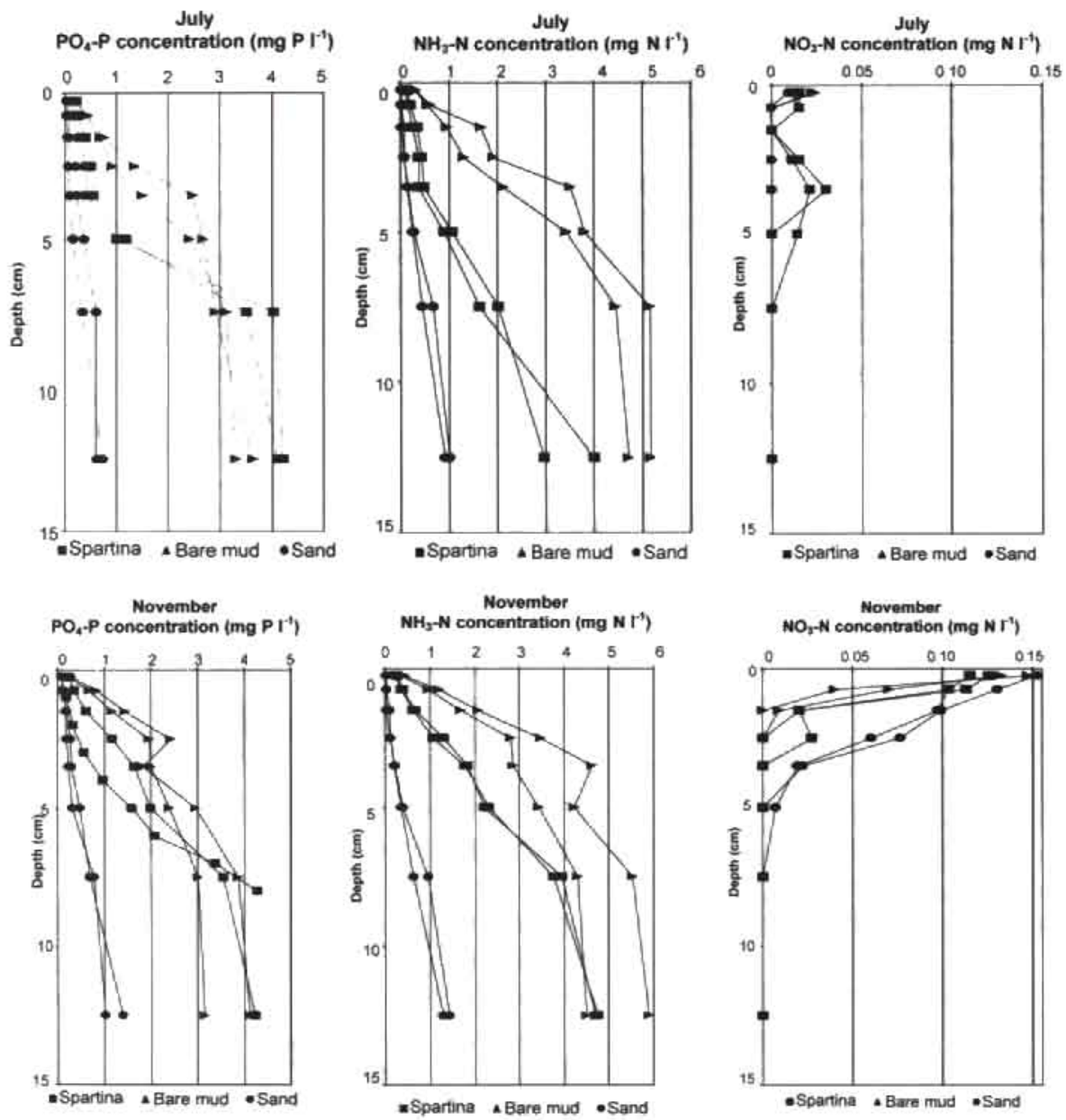

Fig. 5. Sediment porewater concentration of POA-P summer (a) and winter (d). $\mathrm{NH}_{3}-\mathrm{N}$ summer (b) and winter (e). NO- $\mathrm{N}$ at summer ( $\mathrm{c}$ ) and winter ( $\mathrm{f}$ ) in the Spartina, the bare muddy and the bare sandy pooks

250 increased continuously from just above detection limits to $3-4 \mathrm{mg} \mathrm{PO}_{4}-\mathrm{P} \mathrm{I}^{4}$ in the deeper part of the sediment. The Spartina $\mathrm{PO}_{4}-\mathrm{P}$ profile did not show the same rhizosphere depression in fall/winter period as in the summer, and was more comparable to profile in the bare muddy location.

Ammonia porewater profiles.

The same differences existed between the Spartina covered area and the bare muddy area with respect to porewater ammonia concentrations - although more 
pronounced (Fig. 5.b). From an ammonia concentration of about $0.2 \mathrm{mg} \mathrm{NH}-\mathrm{NH}^{-1}$ in the upper part of the bare muddy pools the concentration level increased continuously to $4-5 \mathrm{mg} \mathrm{NH}{ }_{3}-\mathrm{NH}^{\prime}$ in the deeper part during summer sampling. In the Spartina covered area the porewater profile increased from about $0.150 \mathrm{mg} \mathrm{NH}_{3}-\mathrm{N} \mathrm{H}^{-1}$ in the sediment water interface to $1.5 \mathrm{mg} \mathrm{NH}-\mathrm{N} \mathrm{H}^{\prime}$ in $7.5 \mathrm{~cm}$ depth. This was followed by a further increase below the rizosphere in the depth range of $10-15 \mathrm{~cm}$ where the concentration peaked with about $3 \mathrm{mg} \mathrm{NH}-\mathrm{N} \mathrm{H}^{-1}$. In the sandy station the profile increased continuously from about $0.1 \mathrm{mg} \mathrm{NH} \mathrm{N}_{3} \mathrm{~N} \mathrm{I}^{\prime}$ at the sediment surface to a little less than I $\mathrm{mg} \mathrm{NH} 3-\mathrm{NH}^{\prime}$ in the deeper part. The winter profiles of ammonia showed the same tendency (Fig. 5.e). The bare muddy station had again the highest porewater concentrations with about $0.6 \mathrm{mg} \mathrm{NH}-\mathrm{N} \mathrm{H}^{\prime \prime}$ in the sediment water interface steeply increasing to about $4 \mathrm{mg} \mathrm{NH}_{3}-\mathrm{NH}^{-1}$ at $5 \mathrm{~cm}$ depth with a further increase to $5 \mathrm{mg} \mathrm{NH}_{3}$ $\mathrm{NH}^{-1}$ in the deeper part. The Spartina profiles were again depressed in the rhizosphere where the concentration reached $2.5 \mathrm{mg} \mathrm{NH}-\mathrm{N} \mathrm{I}^{1}$ and increased to about $5 \mathrm{mg} \mathrm{NH} 3-$ $\mathrm{NH}^{\prime}$ in the bottom. In the bare sandy area the ammonia concentration was close to zero at the sediment water interface slowly increasing to about I $\mathrm{mg} \mathrm{NH}_{2}-\mathrm{NH}^{-1}$ in the bottom.

Nitrate porewater profiles

Both the bare sandy and bare muddy pools had very low concentrations of nitrate in the top part of the sediment during the summer (Fig 5.c). At both stations the concentration was around $0.020-0.025 \mathrm{mg} \mathrm{NO}_{3}-\mathrm{N} \mathrm{H}^{\prime}$ in the upper part of the sediment and depleted completely at about $1 \mathrm{~cm}$ depth. The Spartina covered bottom followed the same pattern, but increased again down in the rizosphere, where the concentration peaked with about $0.030 \mathrm{mg} \mathrm{NO}{ }_{3}-\mathrm{N}^{\prime}$ ' at 3.0-5.0 $\mathrm{cm}$ depth. Further down the concentration decreased again and was depleted in a depth of $7.5 \mathrm{~cm}$. In the winter period all profiles extended deeper into the sediment (Fig. 5.f). All station had about the same concentration of about $0.150 \mathrm{mg} \mathrm{NO}-\mathrm{N} \mathrm{I}^{\prime \prime}$ in the sediment water interface. The bare mud concentration profile decreased fastest and depleted at a depth of $1.5 \mathrm{~cm}$, where the concentration profile in the plant covered pools depleted at the depth of about $3 \mathrm{~cm}$, while the bare sand concentration profile first depleted at about $7.5 \mathrm{~cm}$ depth.

Phosphorus adsorption

A non-linear regression model (SAS, Nline procedure, no weighting, DUD fitting procedure) the Langmuir adsorption isotherm was introduced and afterward given the measured values of $\mathrm{Ce}$ and SP as input data. The statistical model then predicted values of NAP, K and PSC inside the phosphate concentration range of $0.0-5.0 \mathrm{mg} P \mathrm{O}_{4}-\mathrm{P} \mathrm{H}^{\prime}$. The graph is shown in Figure 6. while the parameter values are presented in Table 1. The Spartina covered pool showed the highest PSC of $140 \mu \mathrm{g} \mathrm{PO} 4-\mathrm{P} \mathrm{g} \mathrm{cm}^{-3}$ sediment and the lowest $\mathrm{K}$ of $400 \mathrm{mg} \mathrm{PO}_{4}-\mathrm{P}^{-1}$. The bare muddy pools also had a high PSC of $80 \mu \mathrm{g} \mathrm{PO} 4 \mathrm{P} \mathrm{g} \mathrm{cm}^{-3}$. but a much higher $\mathrm{K}$ of $2000400 \mu \mathrm{g} \mathrm{PO}-\mathrm{P}^{-1}$. With respect to the 
sandy bare bottom pools they had the lowest PSC of $30 \mu \mathrm{g} P \mathrm{O}_{4}-\mathrm{P} \mathrm{g} \mathrm{cm}$-3 while the $\mathrm{K}$ was equal to that obtained for the muddy pools. The NAP value did not change essentially between the stations. By traditional statistics (SAS, ANOVA, T-test) the three types of pools differed significantly $(P<0.01)$.

Table I. Phosphate adsorption characteristics at the three study sites.

\begin{tabular}{|l|c|c|c|}
\hline & Spartina pools & Bare mud pools & Bare sand pools \\
\hline NAP & 0 & 5 & 10 \\
\hline PSC & 140 & 80 & 30 \\
\hline K & 400 & 2000 & 2003 \\
\hline
\end{tabular}

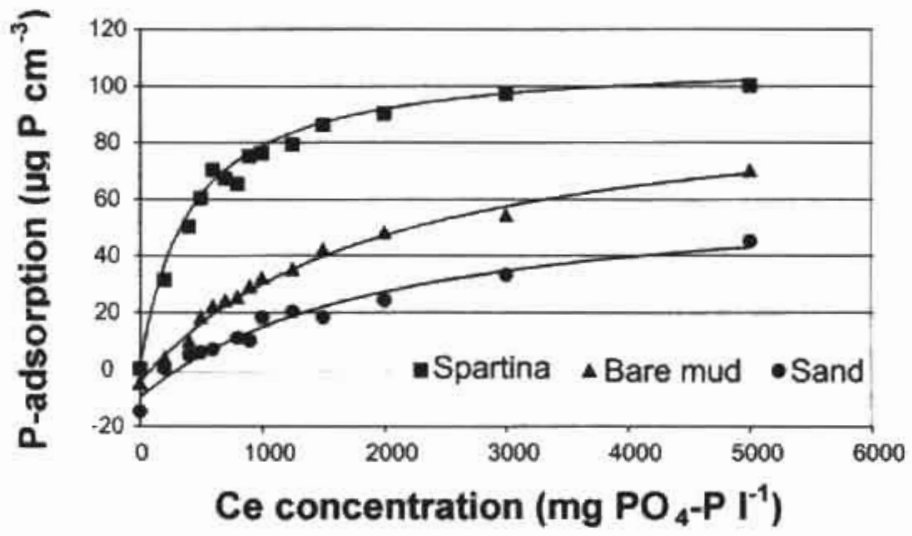

Fig. 6. Phosphate adsorption capacity at the different sites.

\section{Discussion}

The organic content of the different pools are results of local autothropic production, sedimentary processes and the internal nutrient tumover in each pool. The low nutrient content of the sandy pools may be explained by the fact that these pools are located near to the channel where the mass flow of the estuarine water is highest.

252 The current velocities peak with values of about $2 \mathrm{~m} \mathrm{~s}^{-1}$ during spring tide periods (Martins et al. 2002). This means that only small amount of organic matter remains in the area, while the majority becomes resuspended and exported (Flindt et al. 1997, Salomonsen et al. 1997, Flindt et al. 1999, Salomensen 1999). The high nutrient content in the Spartina pools is the results of vice versa processes. The high plant biomass act as a sediment trap for both the local Spartina maritima production as wel as for external produced detritus and macroalgae (Pusceddu et al. 1999). The sediment nutrient content in the different pools showed the same tendency, with much higher nitrogen and phosphorus masses in the Spartina pools compared to the muddy and 
sandy pools. In all three pool types the nutrient content continuously descresed towards the depth. Nutrients did not decresed until a certain level and stayed constant at the last $\mathrm{cm}$. This indicate that the sediment is reworked by biomixing and that the nutrient pools are bioavailable until $15 \mathrm{~cm}$ depth. This is also supported by visual observations where Scrobiculario plana and Carcinus moenos often bring organic matter like Ulvo sp. and Enteromorpha sp. sheets down into the sediment.

The knowledge about macrophyte production is well established, but less is known about the fate of the production. Although, some birds are reported to graze on rooted macrophytes (Tubbs and Tubbs 1983), the grazing is seldom extensive in temperate areas (Mann 1975, Odum et al, 1967). Instead leafs are sloughed with aging or at the end of the growth season, or they are broken or dislodged during periods with violent wave and wind motion. Thus, most of the production enters detrital food webs. Therefore a mineralisation study was initiated to obtain information about the quality of the organic matter in the sediment. Not much qualified information can be harvested from total measurements of nutrients in the sediment if the lability of the particulate organic matter is not quantified (Harrison 1989, Lillebø et al. 1999). Evaluating the particulate organic nitrogen (PON) mineralization in the different pool types, it becomes evident that besides the lowest organic content at the sandy pool, the PON content is also lesser degradable than at the other sites. Together this gives the low porewater concentration of ammonia measured in the present study, which also results in lower flux rates between the sediment porewater and the water column in the sandy pools (Lillebø et al. 2002b). A higher labile fraction of PON was found at both the muddy pool and the Spartina pool with the fastest mineralisation going on in the Spartina pool that also had the highest organic content. Altogether this gives more than double PON turnover in the Spartina pools compared with the muddy bare bottom pools.

Several experiments have been made on the decomposition of Zostera marina and they agree on very low mineralization rates (Mann 1972, Mann 1975. Harrison and Mann 1975. Fenchel 1977. Mann 1982. Harrison 1989. Enriquez et al. 1993. Flindt et al. 1998), which ranges between 0.002 and $0.007 d^{d}$ '. In comparison, the particulate organic nitrogen from the Spartina pools are decomposed much faster than these averages from Zostera marina degradation studies, and within the same temporal range as newly sloughed leaves from Spartina maritima (Lillebø et al. 1999). This indicates that most of the particulate matter in the Spartina pools are based on local production. Although no experiment were performed on the particulate organic phosphorus fraction, it is wellknown that phosphorus mineralization is even faster than the nitrogen mineralisation, while the carbon decomposes slowest of the elements (Flindt et al. 1998).

Evaluating the nutrient porewater concentration of the different pools it is evident that the significant differences exist among them. The pools located on the sand bottom are topographic placed lower than the other pools, which give these pools a mean residence time of only 3 hours per tidal cycle. The muddy pools and the Spartina pools are located further up so the mean residence time for these pools is about 6-8 hours. Alone, this fact has impact on the nutrient profiles and efflux from the different pools. Due to the differences in the nutrient turnover that was found in the mineralisation study it would have been expected that the lowest porewater 
concentration of nutrient would be measured in the sandy pools as we did. Further it was expected that the highest nutrient porewater concentrations would be measured in the Spartina sediment, which was not the case. The highest concentration of ammonia and phosphate was found in the muddy pools. This difference in concentration between the bare muddy pools and the Spartina covered pool may most reasonable be explained by plant uptake, indicating that Spartina maritima affects the efflux rates of dissolved inorganic nitrogen. Comparing the measured porewater concentration from the Spartina pools and the muddy pools from the Mondego estuary with nutrient porewater profiles from other shallow estuaries, the ammonia concentrations are within the same range as measured in the eutrofied broad of Roskilde Fiord, Denmark (Kamp-Nielsen \& Flindt 1993. Flindt 1994, Flindt \& KampNielsen 1998). The phosphate concentrations in the Spartina and the muddy pools are much higher than these found in the Roskilde Fjord indicating that the locations in the Mondego estuary have a higher specific phosphorus loading and a higher P-turnover than the Danish Roskilde Fjord.

Due to the adsorption isotherm the Spartina rhizosphere had the highest adsorption capacity with about $140 \mu \mathrm{g} \mathrm{PO}_{4}-\mathrm{P} \mathrm{cm}^{3}$ sediment, while the bare muddy area in the same depth had a capacity of $80 \mu \mathrm{g} P \mathrm{P}_{-}-\mathrm{P} \mathrm{cm} \mathrm{cm}^{-3}$ sediment. The sandy

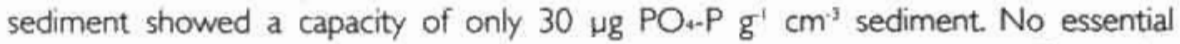
differences existed with respect to NAP between the three sediment types. The major difference in adsorption capacity between the muddy and the Spartina covered pools were due to differences in half saturation level, where the Spartina sediment showed much lesser $K$ values than the bare muddy sediment. This may be explained by differences in sediment iron content giving the Spartina pool a higher adsorption capacity at lower phosphate concentration than these in the muddy pool. The result is that the realised adsorption inside the actual phosphate concentration range of the upper sediment becomes about 3-4 times higher in the Spartina pools than in the bare muddy pools. This fact together with an enhanced phosphate uptake due to plant growth is most properly the reason for the measured difference in the phosphate porewater profiles between the muddy pools and the Spartina covered pools. In the summer period, the Spartina phosphate profile are depressed in the thizosphere compared to the muddy pools, while it is less expressed in the winter profiles.

Although we only found very small internal peaks of nitrate in the porewater profiles of the Spartina covered pool, it indicates that these plant are able to stimulate nitrification. This may only occur if oxygen is present, so most properly the plants realise

254 oxygen or other oxidants from the roots to the porewater. This has also been found for Zostera marina (Flindt 1994), where the plants indirectly were able to stimulate the denitrification inside the plant covered areas. Comparing these to species potential for realising oxygen the root biomass per area of Spartino maritima is much higher than these inside Zostera marina beds (Lillebø 2000).

Altogether, this study indicates that Spartina also is able to control the nutrient dynamic in the intertidal sediment due to two processes: I) Spartina takes up phosphate for growth purposes that without plant coverage would have returned to the watercolumn and 2) the plant does also facilitate increased phosphate adsorption. 
Both process results in a closer coupling of the phosphorus cycle between the plant and the sediment to the benefit for the plant dynamic.

At the system level most pools are situated on bare bottom without connection to rooted vegetation, and these leaks with huge amounts of phosphate, so the intertidal pool system of the Mondego estuary altogether is exporting essential amounts of phosphorus in these years. Lillebø et al. (2002c) have tried to evaluate the internal loading from the different pools over a full discharge year.

The next of this suite of papers concerning the nutrient dynamics in the Mondego estuary will 1) compare the nutrient fluxes and dynamics in the different pools (Lillebø et al. 2002b), 2) demonstrate how macroalgae growt potential are affected by the nutrient fluxes in the different types of pools (Martins et al. 2002) and 3) discuss and perspect the role of the nutrient dynamics in the different pool types on the system level for the Mondego Estuary (Lillebø et al. 2002c).

\section{Acknowledgements}

The present work was supported by the WET-project, (Wetland Ecology and Technology), funded by the European Scientific TMR program (TMR) and the F-ECTS project founded by the European Scientific MAST 3 program inside the ELOISE frame. The authors would also like to thank the freshwater Biological Laboratory, University of Copenhagen, for the analytical support.

\section{References}

Alpkem - 1990. RFA - Metholology A303-\$202 A303-\$170, A303-\$020. ALPKEM Corporaton, Clackamas, Oregon, USA

Amos CL. Brylunsky M.M.M. Sutherland T.F., O'Brian D. Lee S. and Cramp A. 1998. The stability of a mudflat in the Humber estuary, South Yorkshire, UK. p. 25-43. In: Black K.S. Patterson D.M. and Cramp A. (eds). Sedimentary Processes in the intertidal zone. Geological Society, London, Special Publications 139.

Barko J.W. Gunnison D. and Carpenter S.R 1991. Sediment interactions with submersed macrophyte growth and com-munity dynamics. Aquat. Bot. 41:41-65.

Borum J. 1997. Ecology of coastal waters and their response to eutrophication. Chapter 7 In: Freshwater Biology. (Eds. Kaj Sandfensen og Ole Pedersen). Gads Forlag, Copenhagen, Denmark.

Enniques E, Duarte C.M., and Sand-Jensen K. 1993. Patterns in decomposition rates among photosynthetic organisms: the importance of detritus C.N.P content. Decologia 94:457-471

Fenchel T. 1977. Aspects of the decomposition of seagrasses, In eds. McRoy, C.P., Felfferich, C. Seagrass Ecosysterns. Manine Science Vol. 14. Dekker.

Findt M.R. 1994. Measurements of nutrient fluxes and mass balances by on-line in situ dialysis in a Zostero marina bed culture. Vert. Internat. Verein. Limnol. 25: 2259-2264.

Flindt M.R. Kamp-Nielsen L. Marques I.C. Pardal MA. Bocci M. Bendoriccho G., Salomonsen I. Nielsen S.N. and jergensen S.E. 1997. Description of three shallow estuanes: Mondego Rver (Portugal), Roskilde Fjord (Denmark) and the Lagoon of Venice (Italy). Ecol. Model. 102: 17.31

Findt M.R and Kamp-Nielsen L 1998. The influence of sediment resuspension on nutrient metabolism in the eutrophic Roskilde Fjord, Denmark Verh. Internat Verein. Limnol. 26: 1457-146|.

Flindt M.R. Salomonsen J.S., Sendergaard M. and Tomblom E. 1998. Decomposition of Ulva lactuca and Zostera marina. Il. Nutrient dynamics in aerobic and anaerobic experiments. 18 pages. In Salomonsen Ph.d. Theses: 
Investigation and modelling of Ulvo loctuco (L) with special reference to description of decomposition and advective transport

Findt M.R. Pardal MA., Lillebe A.L. Martins L. and Marques J.C. 1999. Nutrient cycling and plant dynamics in estuaries: A bnef review. Acta Oecol 20 (4) 237-248.

Harrison PG. and Mann K.H. 1975. Chemical changes during the seasonal cycle of growth and decay in eelgrass (Zostera marino on the Attantic cost of Canada. J. Fish, Res. Board Can. 32 (5):615-621.

Harrison P.G. 1989. Detrital processing in seagrass systems. A review of factors affecting decay rates. remineralization and detritivory. Aquat. Bot. 23: 263-288.

Jensen H.S. Kristensen P. Jeppesen E and Skytthe A 1992 Ironiphosphorus ratio in surface sediment as an indicator of phosphate release from sediments in shallow lakes. Hydrobiologia 235/236:731.743.

Kamp-Nielsen L 1992 Benthic pelagic coupling of nutnent metabolism along an estuanne eutrophication gradient. Hydrobiologla 235/236: 457-470.

Kamp-Nielsen L and Flindt M.R. 1993. On-line recording of porewater profiles from in Situ dialysis. Verh. Internat. Verein. Limnol. 25; $151-156$.

Lillebo A.L., Findt M.R. Pardal M.A and Marques J.C. 1999. The effect of macrofauna, meiofauna and microfauna on the degradation of Sportino moritima detritus from a salt marsh area. Acta Oecol. 20 (4): 249-258.

Lillebe A.L. Neto J.M., Pardal MA. Findt MR and Marques J.C. 2002a. The role of Spartina maritina and Scirpus moritimus to sediment pore-water profiles, and possible implications to the Mondego estuary nutrent dynamics. Aquatic ecology of the Mondego River Basin Global importance of local experience. (This volume)

Lillebe A.L, Findt M.R. Pardal MA. Martins L, Neto JM. and Marques J.C.2002b. Nutrient dynarnics in the intertidal pools of the Mondego Estuary II - Seasonal efflux of PO.-P and NHL-N in bare bottom and vegetated pools. Aquatic ecology of the Mondego River Basin. Global importance of local experience. (This volume)

Lillebe A.l. Flindt M.R. Pardal M.A. Martins L. Neto J.M. and Marques J.C. 2002c. Nutrient dynamics in the intertidal pools of the Mondego Estuary. N - Pools contribution to the dissolved inorganic phosphate loading, In: Aquatic ecology of the Mondego River Basin. Global importance of local experience. (This volume)

Mann KH. 1972. Macrophyte production and detritus food chains in coastal waters. Mern. Ist. Ital. Idrobiol. Dott Marco Manchi 29:353-383.

Mann K.H. 1975 Decomposition of manne macrophytes. P. 247-267. In J.M.Anderson (ed.). The role of terrestrial and aquatic organisms in the decomposition process. The 17th Symposium of the British Ecological Society.

Marques J.C. Graca MA.S and Pardal. MA. 2002 Introducing the Mondego mver basin. Aquatic ecology of the Mondego River Basin. Global importance of local experience. (This volume)

Martins L. Olveira J.M. Flindt M.R and Marques J.C. 1999. The effect of salinty on the growth of Enteromorpho intestinalis (Chlorophyta) in the Mondego estuary (west Portugal). Acta Oecol. 20 (4): 259-265.

Martins L, Findt M.R. Pardal M.A. Lillebø A.L. Oliveira J.M. and Marques J.C. 2002. Nutrient dynamics in intertidal poots of the Mondego estuary. III - The importance of nutrient effluxes to macroalgal growth (Enteromorpha sp.). Aquatic ecology of the Mondego River Basin. Global importance of local experience. (This volume)

Nixon 5.W. 1995. Coastal Marine Eutrophication: A definition, social causes and future concerns. Ophelia 41: 199.219

Odum E.P. and Cruz AA de la 1967. Particulate onganic detritus in a Georgia salt marsh-estuanine ecosystem, p. 383-388. In G.H. Lauff (ed.). Estuaries. AAAS Publication 83. American Association for the Advancement of Science. Washington. D.C.

256 Pusceddu A, Sarà G., Armeni M., Fabiano M and Mazzola A. 1999. Seasonal and spatial changes in the sediment organic matter of a semi-enclosed marine system (W-Mediterranean Sea). Hydrobiologia 397:59-70

Salomonsen J. Findt MR and Geertz-Hansen O. 1997. Significance of advective transport of UMo loctuco for a biomass budget on a shallow water location. Ecol. Model. $102: 129.132$

Salomonsen J. Flindt M.Rand Geertz-Hansen O. 1999. Modelling advective transport of Ulva loctuca (L) $n$ the sheltered bay, Møllekrogen, Roskilde Fiord, Denmark Hydrobiologia 397: 241-252

Tubbs, C.R and Tubbs J.M. 1983. The distribution of Zostero and its exploitation by wildfowl in the Solent, Southem England. Aquat. Bot. 15: 223-239. 

Série

Investigação

$\bullet$

Coimbra

Imprensa da Universidade

2002 